\section{idenotiune}

Jurnal Kajian Manajemen Dakwah

\title{
Zakat dan Halal: Pengaruh Privilese Praktik Keagamaan Dalam Regulasi Pembangunan di Indonesia
}

\author{
Shiyamil Awaliah \\ Pascasarjana Universitas Islam Negeri Sunan Kalijaga Yogyakarta \\ Email: shiyamilawaliah@gmail.com
}

\begin{abstract}
This paper discusses zakat and halal which are the privileges of religious practice in government regulations to improve the country's economy and community welfare. Methodologically, this study uses a normative juridical approach with qualitative descriptive research. The data were collected through interviews and literature study which were then analyzed and drawn a conclusion. The results of the study show that the government mobilizes the function of Muslim collectivities in religious actions and daily life practices through various policies related to religious norms, such as two policies that have been raised by the government related to zakat regulation and halal regulations. The mobilization aims to improve economic development and community welfare.
\end{abstract}

Keywords: Religion, Government Policy, Economic Development, Community Welfare.

\begin{abstract}
Abstrak: Tulisan ini membahas tentang zakat dan halal yang merupakan privilese praktik keagamaan dalam regulasi pemerintah terhadap meningkatkan ekonomi negara dan kesejahteraan masyarakat. Secara metodologis, kajian ini menggunakan pendekatan yuridis normatif dengan jenis penelitian deskriptif kualitatif. Adapun data dikumpulkan melalui wawancara dan studi kepustakaan yang kemudian dianalisis dan ditarik suatu kesimpulan. Hasil studi menunjukkan bahwa pemerintah memobilisasi fungsi kolektifitas muslim dalam tindakan keagamaan dan praktik kehidupan sehari-hari melalui berbagai kebijakan yang berhubungan dengan norma agama, seperti dua kebijakan yang telah dimunculkan oleh pemerintah terkait pengaturan zakat dan regulasi halal. Mobilisasi tersebut bertujuan untuk meningkatkan pembangunan ekonomi dan kesejahteraan masyarakat.
\end{abstract}

Kata Kunci: Agama, Kebijakan Pemerintah, Pembangunan ekonomi, Kesejahteraan Masyarakat.

\section{Pendahuluan}

Penyesuaian hubungan antara pembangunan dan agama telah terjadi sejak tragedi 9/11. Pihak pembuat kebijakan yang sekularis mulai menyadari bahwa kesalehan dunia meningkat dan agama mulai terlihat di ranah publik, serta banyak mempengaruhi pemikiran pembangunan arus utama. Karena itu, banyak universitas yang membentuk program penelitian, LSM mendirikan pusat studi dan lembaga pembangunan besar seperti World Bank mendirikan lembaga Think Thank, yang semuanya berkaitan dengan agama dan pembangunan. Selain itu, pendanaan untuk organisasi yang berbasis agama meningkat dalam pembangunan. Inisiatif ini muncul dari organisasi-organisasi tersebut yang pada awalnya menghindari isu-isu keagamaan dan menganggap agama sebagai hambatan untuk merealisasikan pembangunan ekonomi dalam kehidupan masyarakat modern yang rasional (Salemink, 2015). Bukan hanya itu, peristiwa 9/11 juga telah membawa peluang kebutuhan untuk memahami lebih baik bagaimana agama dan modernisasi berinteraksi, membuka 
serangkaian masalah baru untuk dialog, misalnya akar dan peran pemikiran gerakan para fundamentalis (Marshall, 2001).

Namun, di sisi lain, lembaga keagamaan juga menunjukkan bahwa mereka memiliki ketertarikan terhadap pembangunan. Secara historis, banyak kelompok agama yang terlibat dalam kegiatan amal dan mengajarkan hal tersebut kepada para pengikutnya seperti zakat di kalangan umat Islam, pemberian jasa di kalangan umat Buddha, serta sumbangan gereja dan pendanaan misionaris di kalangan umat Kristen. Salah satu contoh bentuk bantuan pembangunan adalah zakat. Awalnya, zakat hanya berfokus pada tetangga atau masyarakat miskin dalam ruang lingkup lokal, namun kemajuan globalisasi berhasil memperluas ruang lingkup zakat hingga pada pengentasan kemiskinan tingkat internasional. Aliran dana untuk pengentasan kemiskinaan tersebut bukan hanya berasal dari negara barat, namun aliran dana tersebut juga muncul dari negara mayoritas Muslim ke negara Miskin (Clarke, 2014). Hal ini yang mulai diatur di Indonesia terkait pengaturan zakat. Salah satu tujuan dalam pengaturan tersebut adalah demi tercapainya kesejateraan sosial dan pemerataan ekonomi masyarakat. Artikel ini akan mencoba menjelaskan hal tersebut sebagai bentuk analisis terkait hubungan antara agama dan pembangunan.

Banyak penelitian yang memiliki fokus senada dengan penelitian ini, seperti penelitian Clarke yang membahas tentang bagaimana zakat dapat menjadi salah satu komponen utama ajaran agama Islam yang dapat menjadi solusi untuk pengentasan kemiskinan. Dalan penelitiannya, Clarke juga menjelaskan bahwa aliran dana bantuan internasional yang berbasis Islam telah meningkat di dunia, aliran dana tersebut berasal dari negara-negara Islam seperti Arab Saudi, Iran, dan lain sebagainya. Dari hasil pengamatannya, ia menyimpulkan bahwa pada saat ini umat Islam semakin giat bersedekah dan menggunakannya untuk mendanai kegiatan pengentasan kemiskinan di negara-negara mayoritas Muslim dan non-Muslim. Selain Clarke, Ali juga memiliki penelitian senada, ia menyimpulkan bahwa terlepas dari dokrin keagamaan, zakat berpotensi untuk mengurangi jumlah kemiskinan di dunia. Dana zakat dapat dioptimalkan untuk menarik para penerimanya keluar dari kemiskinan, namun sebaliknya jika pendistribusian dana tidak dikelolah dengan benar, maka tidak akan membawa dampak apapun. Berbeda dari dua penelitian di atas, penelitian ini fokus kepada bagaimana praktik privilese umat Muslim yang dalam hal ini fokus menyoroti zakat dan halal berpengaruh dalam regulasi pembangunan di Indonesia. Zakat dan halal sebagai praktik privilese umat Muslim diatur dalam regulasi pembangunan negara yang kemudian berpengaruh pada pertumbuhan ekonomi masyarakat secara umum.

Pertumbuhan ekonomi tetap menjadi inti teori pembangunan internasional, namun kegagalan strategi pembangunan sangat mencolok, dengan meningkatnya pengangguran, hutang internasional dan meningkatnya tingkat kemiskinan. Sementara faktor historis, politik dan ekonomi seperti krisis hutang tahun 1980-an, perang saudara, dan pembatasan perdagangan tidak diragukan lagi berkontribusi pada fakta ini, Selinger berpendapat bahwa faktor penting yang menyebabkan kegagalan pembangunan disebabkan karena tidak adanya pengakuan budaya, khususnya agama dalam teori dan strategi pembangunan. Budaya dapat didefinisikan sebagai sistem sosial, politik, ekonomi dan agama yang saling berinteraksi untuk menciptakan masyarakat. Selinger juga menjelaskan bahwa, jika ingin mencapai 
sebuah pembangunan yang berhasil dan berkelanjutan, agama sebagai elemen budaya yang sentral dan pasti, harus diperhitungkan dalam proses tersebut (Selinger, 2004).

Sebagaimana yang dijelaskan oleh Heynes bahwa terdapat dua pandangan dalam memahami agama: Pertama, agama dalam arti spiritual, di mana seseorang akan mementingkan transendensi, kesakralan dan keutamaan dalam memandang agama. Ketika memandang agama dalam artian spiritual dalam membicarakan hubungan antara agama dan pembangunan kerapkali diskusi tersebut masuk ke dalam istilah sakral dan sekuler. Kedua, agama dalam arti material, di mana agama mendefinisikan dan menyatukan kelompok atau gerakan sosial, politik yang berbasis masyarakat (Haynes, 2002). Selain itu, ia juga menjelaskan bahwa kebangkitan agama yang kita saksikan sekarang merupakan hasil dari globalisasi dan kemampuan untuk melihat dampak agama pada politik dan masyarakat dalam skala global, dalam artian bahwa agama memiliki kesempatan untuk mengaitkan dirinya dengan politik dan dampaknya pada kehidupan masyarakat. Dalam hal ini untuk menganalisis bagaimana agama dijadikan sebagai alat dalam pembangunan ekonomi dan kesejahteraan masyarakat di Indonesia, artikel ini akan menggunakan pandangan yang kedua dalam mendefinisikan agama.

Agama menyediakan cara bagi setiap individu untuk bersatu dalam era modern akhir yang individualistis. Agama tidak lagi bertindak sebagai sumber stabilitas komunal, finansial, dan moral, tetapi menyangkut penciptaan identitas yang menjadi sebuah faktor yang mendukung prinsip-prinsip modernisasi (Hervieu-Le'ge, 2003). Kemudian argumen ini juga didukung oleh pendapat Ebaugh. Ia menyatakan bahwa orang-orang yang secara aktif memilih untuk mengambil agama sebagai bagian sentral dari identitas individu dan kolektif mereka (Ebaugh, 2002). Artikel ini memandang agama sebagai salah satu sistem budaya yang memiliki peran yang krusial di dalam masyarakat, dengan berpedoman pada argumen Grondona yang menjelaskan bahwa pembangunan hanya akan berkelanjutan jika budaya memiliki sistem nilai yang mendukung pertumbuhan ekonomi. Grondona percaya bahwa pembangunan ekonomi adalah proses budaya dan berpendapat bahwa masyarakat memilih untuk berkembang atau tidak melalui konstruksi budaya yang ada. Akan tetapi artikel ini tidak mengadopsi argument Grondona yang menganggap bahwa agama harus menjadi marginal dalam masyarakat (Grondona, 2000).

Sebagaimana yang dijelaskan oleh Polanyi bahwa pembangunan ekonomi tidak dapat terjadi dalam ruang hampa, dan harus berhubungan dengan masyarakat di mana ia bertindak. Di sebagian besar negara berkembang, ini penting untuk keberhasilan setiap kebijakan pembangunan. Modal sosial, relativisme budaya dan struktur sosial yang akan mengatur dampak kebijakan ekonomi, secara intrinsik terkait dengan pandangan dunia dan dengan demikian agama merupakan pusat dari setiap perkembangan dalam teori pembangunan (Polanyi, 1994). Argumen tersebut didukung oleh Thomas yang menyatakan bahwa dalam kebijakan internasional kita akan mulai melihat agama memiliki efek yang lebih signifikan, dengan kebangkitan politik kerakyatan dan suara yang lebih tegas diciptakan di negaranegara berkembang (Scott, 2000). Selain Thomas, Douglas Johnston juga mendukung argumen tersebut dengan mengusulkan peningkatan pengakuan terhadap agama dalam 
kebijakan pemerintah dan agensi, tetapi menginginkan ini terjadi sehubungan dengan konteks dan situasi politik, serta mengembalikan agama pada masyarakat (Johnston, 2001).

Sebagai agama yang dianut oleh mayoritas penduduk Indonesia, Islam dan berbagai aspeknya senantiasa menarik untuk didiskusikan. Terlebih lagi umat Islam di Indonesia juga mempunyai perhatian terhadap banyak persoalan dan ingin berkontribusi didalamnya. Mereka tidak hanya sibuk bergulat dan larut dengan persoalan ibadah tapi juga ingin berperan dalam persoalan sosial kemasyarakatan (Thohari, 2015). Di zaman modern, terdapat dua perubahan yang saling terkait, yaitu pertama karena agama telah dibangun secara global sebagai intensitas yang bersatu dan dapat dikenali, agama juga semakin dikelola oleh negara sebagai seperangkat layanan yang dapat berkontribusi pada penyediaan kesejateraan di masyarakat. Kedua, agama-agama yang terglobalisasi secara konstan dan tak terhindarkan ditarik ke dalam ruang global yang kemudian diubah menjadi gaya hidup dan menjadi lembaga yang menawarkan komoditas dan layanan yang memenuni kebutuhan para penganutnya (Turner, 2011). Dalam konteks Indonesia, hal tersebut mulai diatur dalam sebuah regulasi oleh negara, hal ini dapat dilihat dari bagaimana negara mengatur budaya ataupun praktek keagamaan masyarakat dalam kehidupan sehari-hari, seperti regulasi halal. Pada negara berkembang, praktik halal diatur oleh negara dalam sebuah regulasi sebagai salah satu bentuk strategi pembangunan. Hal tersebut dapat dilihat sebagai bentuk hubungan yang signifikan agama dalam pembangunan.

Berdasarkan penjelasan di atas, tulisan ini akan mengkaji tentang pengaruh agama dalam pembangunan ekonomi dan meningkatkan kesejahteraan masyarakat Indonesia. Artikel ini akan memandang agama sebagai salah satu sistem budaya yang dapat memberikan pengaruh yang signifikan dalam strategi pembangunan di Indonesia. Selanjutnya dalam menganalisis hal tersebut, artikel ini akan memberikan dua contoh studi kasus yang dapat menunjukkan bagaimana agama dapat memberikan pengaruh yang signifikan dalam pembangunan ekonomi dan pemerataan kesejahteraan sosial melalui praktik dan fungsi kolektivitas masyarakat muslim. Hal tersebut dapat dilihat bagaimana negara mulai mengatur praktek tersebut dalam sebuah regulasi.

\section{Metode}

Secara metodologis, penelitian ini menggunakan pendekatan yuridis normatif dengan jenis penelitian deskriptif kualitatif. Adapun data dikumpulkan melalui wawancara dan studi kepustakaan. Adapun informan penelitian ini terdiri dari 4 orang, yaitu Khuriati, Sakinah, Aziz Muslim, dan Satrio. Penelitian ini akan menelaah hubungan antara agama dan pembangunan melalui dua studi kasus, yaitu praktik zakat dan halal yang diatur ke dalam sebuah regulasi. Pengaturan tersebut tidak terlepas dari intervensi negara yang memobilisasi praktik keagamaan sehari-hari masyarakat untuk meningkatkan pembangunan ekonomi di Indonesia. Melalui hal tersebut artikel ini berkontribusi pada sosiologi agama dan pembangunan, di mana agama menjadi salah satu faktor yang krusial dalam mencapai peningkatan taraf pembangunan. Selain itu, artikel ini juga akan menelaah lebih jauh bagaimana agama dan pembangunan dapat berjalan seiring untuk merealisasikan strategi pembangunan. 


\section{Hasil dan Pembahasan \\ Zakat Dalam Pemerataan Kesejahteraan dan Pembangunan Ekonomi}

Kesadaran kolektif dalam gerakan filantropi Islam telah melalui proses evolusi yang cukup panjang dan dinamis. Hal ini terbukti dengan munculnya aktor-aktor pegiat filantropi Islam dengan berbagai latar belakang organisasi yang berbeda, baik organisasi masyarakat sipil berbasis komunitas, organisasi yang berorientasi profit dan organisasi negara. Evolusi kelembagaan filantropi mulai terlihat di Indonesia sejak tahun 1960 dan 1970-an, ketika keterlibatan pemerintah, baik dalam konteks regional maupun nasional dalam mengatur regulasi pengelolaan dana-dana masyar akat yang berasal dari zakat semakin jelas. Meski belum sepenuhnya berjalan secara efektif, pada akhir tahun 1960-an sampai 1970-an beberapa kebijakan pemerintah tentang kegiatam filantropi Islam di Indonesia sudah muncul melalui tangan kementerian agama maupun pemerintah daerah (Ichwan, 2005). Sebagaimana yang dijelaskan oleh Amelia Fauziah bahwa selama dan sesudah masa kolonial hingga masa orde baru, praktek zakat di Indonesia tidak pernah terlepas dari intervensi pemerintah (Fauzia, 2008).

Budaya memberi dapat merepresentasikan simbol solidaritas, ketaatan keagamaan, kohesi sosial dan dapat menjadi cara untuk menciptakan relasi patron-klien, serta merupakan ekspresi kebanggaan, kekuatan dan dominasi. Di kalangan masyarakat muslim, tradisi memberi baik dalam bentuk kewajiban membayar zakat maupun bersedekah telah menjadi salah satu sumber untuk mendorong kemaslahatan masyarakat. Oleh sebab itu, peran negara dalam mengatur hal tersebut semakin kuat. Beberapa negara seperti Malaysia, Pakistan dan Indonesia, serta negara-negara lain di wilayah Teluk telah menyaksikan fakta semakin kuatnya peran negara dalam mengatur dan bahkan mengorganisasi pelaksanaan zakat (Latief, 2017).

Zakat sebagai sarana dukungan dan bantuan bagi orang miskin dan yang membutuhkan adalah perintah ilahi. Ini mencerminkan fokus kuat Islam pada keadilan sosial dan ekonomi dan berfungsi untuk menyediakan, melalui penegakan kewajiban sosial, langkah-langkah fiskal, dan tanggung jawab hukum, redistribusi kekayaan yang adil dan merata. Fungsi mendasarnya sebagai praktik keadilan sosial adalah, melalui pertumbuhan yang adil bagi semua anggota, untuk mengurangi penderitaan dan menjaga harmoni dan stabilitas dalam masyarakat. Zakat adalah kewajiban keuangan tahunan yang ditentukan untuk semua Muslim yang mampu secara finansial dan merupakan lembaga dasar yang berupaya untuk memenuhi kebutuhan orang miskin dan yang membutuhkan dalam bentuk sistem keamanan sosial-ekonomi yang mapan. Zakat adalah praktik yang diperkenalkan oleh Nabi Muhammad di bawah instruksi langsung Tuhan dan dipandang oleh umat Islam sebagai kewajiban agama bagi semua umat beriman (Ali, 2014).

Berdasarkan penjelasan tersebut, melihat potensi zakat yang cukup besar untuk meningkatkan kesejahteraan peran negara dalam mengatur zakat tersebut semakin kuat. Seperti di Indonesia, negara mengatur praktek tersebut dalam sebuah regulasi. Hal ini menunjukkan bahwa zakat sebagai bentuk praktek ketaatan beragama dalam Islam dapat menjadi sebuah kekuatan kolektif dalam meningkatkan kesejateraan dalam masyarakat Indonesia. Dalam pengaturan zakat terjadi kerjasama antara lembaga keagamaan ataupun aktor non pemerintah 
dengan negara. Jika pengaturan terhadap praktek zakat tersebut dapat berjalan secara maksimal, maka akan dapat membawa perubahan dan kesejahteraan dalam pembangunan berkelanjutan di Indonesia. Hal ini merupakan fakta bahwa, praktek-praktek keagamaan dapat menjadi instrument dalam meningkatkan strategi pembangunan. Hal ini juga menunjukkan bahwa terlepas dari diskusi sacral, sekuler ataupun profan, agama memiliki hubungan yang signifikan dalam pembangunan.

\section{Halal: Regulasi atau Praktik dalam Kehidupan Sehari-Hari?}

Dalam beberapa tahun terakhir, tren global telah menunjukkan bahwa bisnis barangbarang Islami sedang berkembang pesat, hal ini dapat dilihat dengan munculnya berbagai produk yang menggunakan simbol dan nilai-nilai agama seperti stiker, permadani, kartu liburan, dan plakat dengan menggunaan kaligrafi Islam hingga jenis liburan khusus yang ditujukan untuk umat Muslim (Fischer, 2011). Permintaan akan layanan dan objek keagamaan telah menciptakan pasar keagamaan global di mana umat Islam ingin mengkonsumsi layanan yang berkaitan dengan norma dan nilai-nilai keagamaan (Turner B. , 2010).

Potensi pasar internasional produk halal tumbuh seiring dengan pertumbuhan populasi muslim dan penyebaran tradisi Islam. Hal ini dapat dilihat dari sebuah studi pemerintah Kanada pada tahun 2006 yang menyatakan bahwa perdagangan halal global setiap tahunnya berjumlah \$ 150 miliar, dan pertumbuhan Muslim di dunia meningkat sekitar 1,3 miliar (Fischer, Halal, Haram, or What?: Creating Muslim Space in London, 2009). Pada saat yang sama, barang-barang dari produk halal tersebut dibeli oleh konsumen yang bukan hanya anggota dari agama Islam. Hal ini disebabkan karena mereka menganggap tren halal sebagai suatu komoditas produk yang sehat, tren seperti ini baik untuk perkembangan pasar internasional khususnya produk-produk yang berlabel halal (Gabdrakhmanov, 2016). Hal yang sama juga dijelaskan oleh Fischer bahwa produk halal semakin diakui oleh umat Muslim dan non-Muslim secara global sebagai produk yang bersih dan aman diera penyakit dan bencana kesehatan yang disebabkan oleh gaya hidup yang tidak sehat (Fischer, 2011) (Haenni, 2009).

Hal ini juga sejalan dengan yang disebut oleh Timur Kuran sebagai logika dasar ekonomi Islam, sebagai bagian dari respon terhadap keluhan masyarakat kontemporer dan merupakan instrument untuk memajukan agenda politik Islamisme. Ekonomi Islam menunjukkan banyak kesiapan untuk menerima kenyataan pasar dan bekerja dalam logika kapitalisme untuk meningkatkan kekuatan ekonomi dan politik Islam (Kuran, 2006). Sebagaimana yang dibahas oleh Keymen tentang bagaimana Islam di Turky telah menjadi aktor ekonomi yang kuat dan tampaknya bertujuan untuk mempromosikan modernisasi ekonomi bermuatan moral yang didasarkan pada kombinasi pasar bebas dan nilai-nilai agama (Keyman, 2005).

Halal adalah kata Arab yang secara harfiah berarti "diizinkan" atau "halal". Secara konvensional, halal menandakan "makanan murni" berkaitan dengan daging khususnya dengan praktik Islam yang benar seperti penyembelihan ritual dan menghindari daging babi. Di dunia modern, halal tidak lagi merupakan ekspresi bentuk esoteris dari produksi, 
perdagangan, dan konsumsi tetapi bagian dari pasar global yang besar dan berkembang (Fischer, 2011).

Di era gobalisasi ini, halal telah menjelma menjadi sistem politik, spiritual bahkan menjadi identitas budaya tradisional. Halal menjadi panduan dalam kebersihan makanan. Halal bersifat global tetapi diekspresikan melalui etika praktis yang bersifat pribadi dan komunal (Mukherjee, 2014). Jika dipandang dalam konteks Indonesia, penulis memahami bahwa halal menjadi bagian dari gaya hidup masyarakat mayoritas dan telah melekat dalam struktur kehidupan sehari hari.

Pada Negara-negara yang memiliki pluralism keagamaan, Islam memiliki kedudukan penting, hal ini disebabkan karena dua hal, pertama, sebagai pandangan dunia yang merupakan bagian dari kebudayaan lokal, Islam memberikan dukungan bagi munculnya ideology asli, dimana Islam diakui sebagai sumber hukum yang ideal bagi tradisi kebudayaan lokal. Kedua, Islam dapat menjadi penghalang terjadinya persatuan nasional karena memperkuat identitas tertentu dari bagian suatu masyarakat dan arena itu mendorong timbulnya konflik atau separatism (Bush, 2008). Hal ini telah terjadi dalam revolusi Iran pada tahun 1979 mengakibatkan munculnya Negara agama yang menunjukkan kekuatan agama sebagai proyek politik vital untuk memobilisasi masyarakat dan transformasi Negara. Klaim identitas Islam merupakan politik identitas yang beroperasi dalam modernitas dan menuntut pengakuan (Keyman, 2007).

Namun, artikel ini fokus pada bagaimana praktek keagamaan masyarakat dalam kehidupan sehari-hari mulai diatur oleh negara dalam sebuah regulasi. Praktek tersebut diatur dalam regulasi halal, yang mana regulasi tersebut dapat membawa potensi yang cukup besar dalam pembangunan ekonomi masyarakat. Halal dalam hal ini dipahami sebagai norma agama yang dipraktekkan oleh masyarakat muslim dalam kehidupan sehari-hari. Selain itu halal dalam hal ini telah berkembang menjadi kekuatan pasar yang sangat potensial. Melihat perkembangan tersebut, negara mulai mengatur halal dalam sebuah regulasi, dimana setiap produk yang beredar di Indonesia harus memiliki sertifikasi halal, yang mana proses sertifikasi produk tersebut diatur oleh negara. Kemudian, melalui regulasi tesebut dapat dipahami bahwa nilai-nilai agama yang dalam hal ini merupakan praktek dalam kehidupan sehari-sehari memainkan peran yang cukup krusial dalam strategi pembangunan di Indonesia.

Seperti yang dijelaskan oleh Turner bahwa dengan globalisasi agama, formasi agama modern sangat dipengaruhi oleh globalisasi kehidupan ekonomi, khususnya oleh komodifikasi kehidupan sehari-hari. Agama menjadi bagian dari system ekonomi global dalam hal sirkulasi komoditas keagamaan (Turner B. S., 2011). Melalui sirkulasi komoditas keagamaan tersebut, yang mana pada awalnya halal hanya sebatas budaya ataupun praktek keagamaan dalam kehidupan sehari-hari dan bersifat individual kemudian menjadi suatu kekuatan yang bersifat kolektif. Kekuatan tersebut membawa pengaruh yang cukup besar dalam pembangunan ekonomi masyarakat, hal tersebut jugalah yang telah menarik perhatian pemerintah untuk mengatur hal tersebut dalam sebuah regulasi halal, pengaturan regulasi tersebut merupakan salah satu strategi dalam pembangunan ekonomi di Indonesia. 


\section{Pengaruh Zakat dan Regulasi Halal dalam Pembangunan}

Filantorpi merepresentasikan aksi-aksi kolektif masyarakat, dan merupakan alat penting dalam upaya kolektif unuk menyelesaikan persoalan-persoalan kehidupan masyarakat, seperti pengentasan kemiskinan, perwujudan kesejahteraan public, pemerataan keadilan sosial dan penguatan demokrasi (Latief, 2017). Di Indonesia kegiatan zakat tersebut diatur dalam Undang-Undang nomor 23 tahun 2011 tentang pengelolaan zakat dan di dukung oleh instruksi presiden nomor 3 tahun 2014 tentang Optimalisasi Pengumpulan Zakat Di Kementerian/Lembaga Melalui Badan Amil Zakat Nasional. Pada salah satu pasal dalam UU tersebut menyebutkan bahwa dana zakat tersebut diatur dan dikelolah oleh lembaga resmi yaitu BAZNAS.

Survei PIRAC 2007 mengungkapkan bahwa jumlah rata-rata zakat yang dibayarkan oleh muzakki meningkat dari Rp. 416.000/orang/tahun (2004) menjadi Rp. 684.500/orang/tahun (2007). Berdasarkan data-data ini, PIRAC memperkirakan potensi zakat pada tahun 2007 mencapai Rp. 9,09 triliun. Jumlah ini meningkat hampir dua kali lipat jika dibandingkan dengan potensi zakat tahun 2004 yang jumlahnya mencapai Rp. 4,45 triliun. Dengan jumlah tersebut, maka potensi dana zakat yang bisa dihimpun dari masyarakat mencapai 6.132 triliun per tahun. Saat ini baru 12,5\% dana zakat masyarakat yang sudah dikelola dengan baik oleh lembaga resmi seperti BAZ maupun LAZ. Berdasarkan hasil penelitian yang dilakukan oleh pihak Kemenag dan Baznas potensi zakat di Indonesia dapat mencapai Rp 217 triliun. Namun pada tahun 2010 potensi zakat yang dikelola oleh Baznas hanya mencapai Rp 1,5 triliun. Sedangkan pada tahun 2012 diprediksi potensi potensi pengelolaan zakat hanya mencapai 2 triliun (Sintha Dwi Wulansari, 2014).

Melihat jumlah yang cukup besar tersebut, aka membawa dampak yang cukup besar tehadap pemerataan keejateraan di Indonesia. Sebagaimana yang dijelaskan oleh Latief bahwa Malaysia dan Indonesia merupakan dua negara di Asia Tenggara yang melakukan banyak inovasi praktek filantropi Islam, termasuk dalam menggalang dana-dana zakat dan sedekah. Inovasi praktek zakat ini dapat dilihat dari usaha-usaha pemerintah untuk melaksanakan konsep-konsep baru seperti zakat profesi dan zakat perusahaan (Latief, 2017).

Sebagai salah satu contoh adalah alokasi dana zakat profesi dari karyawan Bank BRI, dana tersebut mencapai 6 Milyar per bulan yang dihasilkan dari pemotongan gaji karyawan sebesar 2,5\% terhitung sebagai zakat, yang mana dana tersebut dikelolah oleh yayasan baitul maal BRI kantor pusat. Sebagian besar dana tersebut dialokasikan untuk beasiswa tingkat SD hingga perguruan tinggi untuk anak-anak yang kurang mampu, adapun jumlah anak yang memperoleh beasiswa tersebut pada tahun 2012 berjumlah 12.000 anak yang tersebar di Indonesia (VOA-Islam.com, 2013). Selain itu pemotongan gaji untuk zakat profesi juga terjadi dikalangan dosen sebagai Pegawai Negeri Sipil. Seperti aturan yang berlaku di UIN Sunan Kalijaga bahwa pegawai minimal golongan 3 akan menerima potongan gaji sebesar 2,5\% perbulannya terhitung sebagai zakat profesi, akan tetapi peraturan tersebut tidak bersifat mengikat, bagi pegawai yang merasa keberatan akan hal tersebut dapat mengajukan surat kepada LAZ UIN Sunan Kalijaga. Dana dari pemotongan gaji tersebut sebagian besar juga dialokasikan untuk beasiswa bagi mahasiswa yang kurang mampu (Muslim, 2019). Hal ini 
dapat membawa dampak yang cukup signifikan dalam pembangunan berkelanjutan di Indonesia.

Menurut keterangan beliau bahwa dari keseluruhan dosen UIN hanya $10 \%$ yang bersedia gajinya dipotong sebesar $25 \%$ perbulannya. Sebagian yang lain hanya bersedia dipotong sebesar 50.000-100.000 perbulannya. Dari jumlah keseluruhan zakat profesi yang dihasilkan dari UIN berjumlah 21 juta perbulannya, sebagian besar dana tersebut disalurkan untuk beasiswa untuk mahasiswa kurang mampu. Jika zakat profesi dapat dikelolah dengan baik dan kesadaran akan zakat profesi meningkat, maka hal tersebut akan membawa dampak yang sangat signifikan untuk pembangunan berkelanjutan seperti pemberian beasiswa untuk meningkatkan taraf pendidikan anak bangsa.

Selain itu menurut informan yang lain bahwa selain untuk bantuan pendidikan, sejauh yang kami tau bahwa sebagian dana dari pemotongan gaji kami setiap bulannya dialokasikan untuk membantu para lansia yang sudah tidak mampu bekerja. Bagi kami hal ini membawa pengaruh yang cukup besar untuk pemerataan kesejahteraan masyarakat (Khuriati, 2019). Selanjutnya Sakinah menambahkan argument tersebut bahwa meskipun negara tidak mengatur terkait zakat profesi, kami dari guru-guru juga tetap akan mengeluarkan zakat tersebut. Namun karena negara mengatur, kami cukup senang karena kami merasa bahwa siapapun yang memotong untuk zakat tersebut tidak masalah selama itu untuk membantu orang-orang yang membutuhkan (Sakinah, 2019). Dari penjelasan tersebut dapat dilihat bahwa, kesadaran masyarakat untuk membantu sesama semakin meningkat. Berdasarkan hal tersebut dapat dinyatakan bahwa dengan meningkatnya kesadaran masyarakat dalam hal ini PNS akan mempermudah upaya pemerintah untuk mengatur hal tersebut dalam sebuah regulasi. Hal ini menunjukkan bahwa fungsi kolektifitas masyarakat dapat membawa pengaruh yang besar terhadap pemerataan kesejahteraan.

Berdasarkan penjelasan tersebut dapat dilihat bahwa dana zakat dapat membawa dampak yang cukup besar dalam pemerataan kesejateraan di Indonesia. Sebagaimana dicontohkan diatas, bahwa sebagian besar dana zakat tersebut dialokasikan untuk pemberian beasiswa bagi anak-anak yang tidak mampu, hal tersebut dapat membawa perubahan dalam masyarakat dari segi pendidikan, ihwal ini juga dapat menjelaskan bahwa ketaatan terhadap praktek keagamaan muslim yang dipandang sebagai bagian dari agama dapat membawa pengaruh yang cukup besar dalam pembangunan.

Berbeda dengan regulasi halal, halal membawa pengaruh yang berbeda dengan pengaturan zakat dalam konteks pembangunan. Pengaturan tentang regulasi halal di Indonesia lebih mambawa dampak pada perluasan pasar produk halal Indonesia. Hal ini membawa dampak yang cukup signifikan terhadap pembangunan ekonomi masyarakat. Salah satu bentuk pengaruh regulasi halal terhadap pembangunan ekonomi di Indonesia yaitu dengan berkembangnya beberapa sektor terkait seperti halal food, busana Muslim syar'i, halal travel dan tourism, syariah banking finance and property, serta Islamic education and training. Dengan berkembangnya berbagai sektor tersebut akan membawa dampak pada pertumbuhan ekonomi masyarakat Indonesia dan meningkatnya pendapatan negara. Seperti yang dijelaskan oleh sebuah akun instagram yag bernama halalexpo-id, akun ini dikelolah oleh Satrio perwakilan dari WP Citra Exhibition. Perusahaan tersebut bekerjasama dengan 
beberapa kementerian dan lembaga yang terkait dengan halal di Indonesia, di mana akun tersebut memberikan edukasi, sosialisasi terkait regulasi halal dan perkembangannya di Indonesia, sebagaimana berikut:

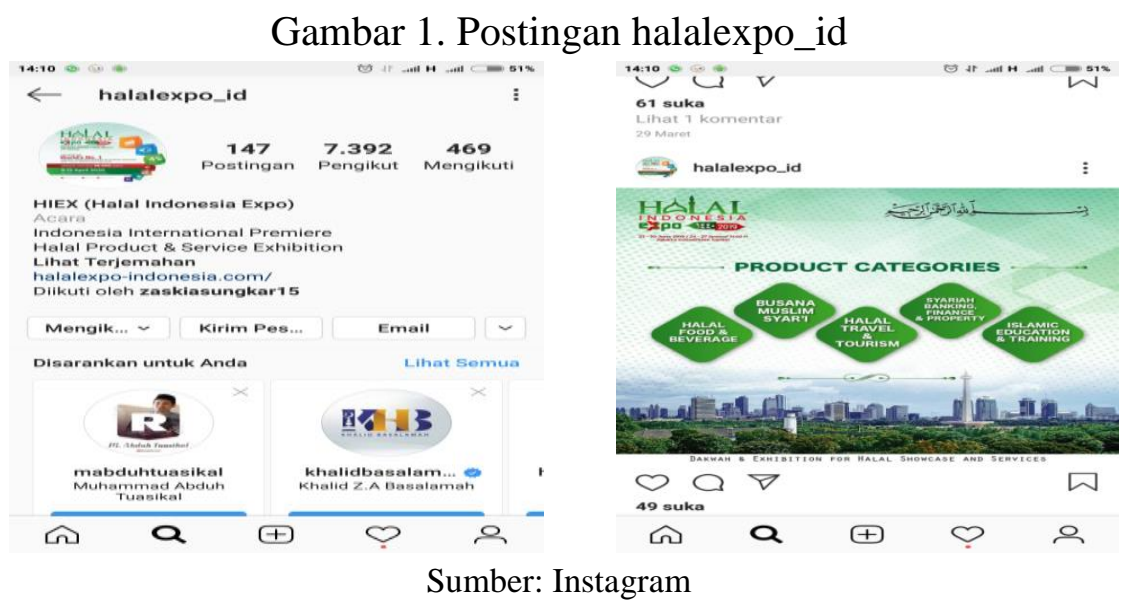

Menurut keterangan admin akun tersebut, bahwa halal telah membawa pengaruh yang sangat signifikan terhadap pembangunan ekonomi. Hal tersebut dapat dilihat dari semakin banyaknya produsen produk makanan dan jasa yang berkembang di Indonesia, yang mana perkembangan tersebut bukan hanya dari kalangan perusahaan besar, namun juga pada industri-industri kecil seperti industri rumah tangga. Lebih lanjut Satrio menjelaskan bahwa perkembangan tersebut didukung oleh tingkat kesadaran masyarakat terhadap halal yang semakin meningkat (Satrio, 2019).

Namun demikian, pengaruh regulasi halal bukan hanya di bidang produk konsumsi saja namun juga mencangkup produk jasa seperti pariwisata halal. Kegiatan pariwisata tersebut dapat membawa pengaruh yang cukup besar terhadap pertumbuhan ekonomi di Indonesia. Dalam jangka waktu tiga tahun terakhir, wisata halal Indonesia mengalami peningkatan sebesar $15,5 \%$. Selain itu kemenpar menyatakan bahwa total pengeluaran wisatawan muslim dunia 2014 lalu mencapai 142 miliar dolar AS. Dari data tersebut menyatakan bahwa sementara pertumbuhan halal tourism Indonesia mencapai 6,3\%, angka tersebut lebih tinggi dari rata-rata pertumbuhan pariwisata dunia, seperti yang dijelaskan oleh akun instagram terebut sebagai berikut:

Gambar 2. Postingan halalexpo_id 26 Maret 2019
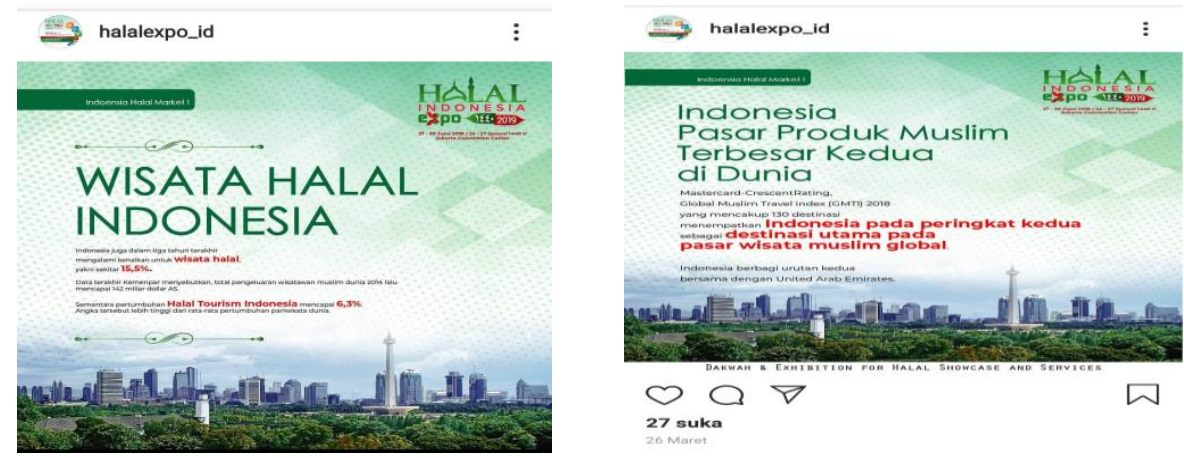

Sumber: Instagram 
Data tersebut menunjukkan bahwa Mastercard crescentrating, Global Muslim Travel Index (GMTI) 2018 yang mencakup 130 destinasi menempatkan Indonesia pada peringkat kedua sebagai destinasi utama pada pasar pariwisata Muslim global. Data tersebut juga menjelaskan bahwa kegiatan wisata halal membawa dampak yang cukup besar dalam peningkatan pertumbuhan ekonomi masyarakat dan meningkatkan pendapatan negara. Dengan demikian, dapat dijelaskan bahwa halal sebagai bagian dari budaya dalam kehidupan sehari-hari masyarakat Muslim yang mulai diatur oleh pemerintah dalam sebuah regulasi hingga pada akhirnya menjadi sebuah kekuatan kolektif yang dapat membawa pengaruh cukup besar dalam meningkatkan ekonomi masyarakat di Indonesia.

\section{Simpulan}

Dari berbagai penjelasan diatas dapat disimpulkan bahwa, pemerintah Indonesia memobilisasi fungsi kolektifitas umat Muslim menjadi sebuah strategi dalam meningkatkan pembangunan ekonomi dan meningkatkan kesejateraan masyarakat. Fungsi kolektifitas yang dimaksud dalam hal ini merupakan kegiatan zakat dan halal yang merupakan bagian dari budaya dalam kehidupan sehari-hari masyarakat Muslim yang awalnya bersifat individu kemudian diatur oleh pemerintah melalui sebuah regulasi yang pada akhirnya menciptakan sebuah kekuatan yang bersifat kolektif. Hal ini membawa dampat yang cukup signifikan dalam pembangunan ekonomi dan meningkatkan kesejahteraan masyarakat di Indonesia. Dengan demikian dapat dinyatakan bahwa, agama yang dalam hal ini dipandang sebagai salah satu unsur dari budaya yang melekat pada masyarakat Muslim di Indonesia memainkan peran yang krusial dalam strategi pembangunan. Hal tersebut menunjukkan bahwa terlepas dari diskusi profan, sacral, sekuler dan sebagainya, agama perlu diperhitungkan sebagai komponen penting dalam diskusi pembangunan, sebab agama tidak dapat dilepaskan dari kegiatan sosial masyarakat, yang mana merupakan objek dari pembangunan itu sendiri.

\section{Referensi}

Bush Robin, and Feener, R. Michael, Religion and the Politics of Development, (New York: Palgrave Macmillan, 2015), 35-60.

Bush, Robin, "Regional Sharia Regulations in Indonesia: Anomaly or Symptom?", dalam Greg Fealy and Sally White, (Eds.) Expressing Islam: Religious Life and Politics in Indonesia, (Singapore: Institute of Southeast Asian Studies, 2008), 174-191.

Clarke, Matthew, "Islamic International Aid Flows for Poverty Alleviation", dalam Matthew Clarke and David Tittensor, Islam and Development, (England: Ashgate Publishing, 2014), 51-68.

Ebaugh, Helen Rose, "Presidential Address 2001, Return of the Sacred: Reintegrating Religion in the Social Sciences', Journal for the Scientific Study of Religion, 41/3, (2002), 385-395.

Fauzia, Amelia, Faith and the State: the History of Islamic Philanthropy in Indonesia, Disertasi (Melbourne: The Asia Institute, The University of Melbourne, 2008).

Fischer, Johan, The Halal Frontier Muslim Consumers in a Globalized Market, (New York: Palgrave Macmillan, 2011), 43. 
Fischer, Johan, "Halal, Haram, or What?: Creating Muslim Space in London, dalam dalam Johanna Pink, Muslim Societies in the Age of Mass Consumption: Politics, Culture and Identity between the Local and the Global, (Cambridge: Cambridge Scholars Publishing, 2009), 3-22.

Gabdrakhmanov, Biktimirov, Rozhko, dan Khafizova, "Problems Of Development Of Halal Tourism In Russia", Journal of Organizational Culture, Communications and Conflict, Vol 20, No 2, (2016), 88-93.

Grondona, Mariano, "A Cultural Typology of Economic Development', dalam L. E. Harrison and S. P. Huntington, Culture Matters: How Values Shape Human Progress, (New York: Basic Books, 2000), 43-58.

Hervieu-Le'ger, Danièle, "Individualism, the Validation of Faith and the Social Nature of Religion in Modernity" dalam Richard K. Fenn, The Blackwell Companion to Sociology of Religion, (Oxford: Blackwell, 2003), 160-172.

Ichwan, Moch. Nur, "Official Reform of Islam: State Islam and the Ministry of Religious Affairs in Contemporary Indonesia, 1966-2004", Dissertation, (Universiteit van Tilburg, 2005).

Jeffrey, Haynes, "Religion', dalam L. Gearon, Human Rights and Religion: A Reader, (Brighton: University of Sussex Press, 2002), 17-29.

Johnston, Douglas, "Religion, Culture and Globalization'” dalam R. L. Kugler and E. L. Frost, The Global Century: Globalization and National Security, (Washington: National Defense University Press, 2001), 7.

Keyman, Fuad, "Modernity, Secularism and Islam The Case of Turkey", Theory, Culture \& Society, Vol. 24 No 2 (2007), 215-234.

Latief, Hilman, Politik Filantropi Islam di Indonesia: Negara, Pasar dan Masyarakat Sipil, (Yogyakarta: Ombak, 2017), 13.

Marshall, Katherine, "Development and Religion: A Different Lens on Development Debates", Peabody Journal of Education, Vol. 76, No. 3/4, Global Issues in Education (2001), 339-375.

Polanyi, The Great Transformation: The Political and Economic Origins of Our Time, (Boston, MA: Beacon Press, 1994), 85.

Salemink, Oscar, "The Furification, Sacralisation and Instrumentalisation of Development", dalam Philip Fountain, Robin Bush and R. Michael Feener, Religion and the Politics of Development, (New York: Palgrave Macmillan, 2015), 35-60.

Selinger, Leah, "The Forgotten Factor: The Uneasy Relationship between Religion and Development", Social Compass, 51/4, (2004), 523-543.

Scott M, Thomas, "Taking Religious and Cultural Pluralism Seriously: The Global Resurgence of Religion and the Transformation of International Society', Millennium: Journal of International Studies, 29/3, (2000), 815-841.

Thohari, Hajriyanto Y, Islam, Urusan Kemanusiaan dan Kebangsaan, dalam Hilman Ltief dan Zezen Zaenal Mutaqin, Ilam dan Urusan Kemanusiaan: Konflik, Perdamaian dan Filantropi, (Jakarta: Serambi Ilmu Semesta, 2015) 
Turner, Bryan S, Religion and Modern Society: Citizenship, Secularisation and the State, (New York: Cambridge University Press, 2011), 271-297.

Turner, Bryan S, Islam, "Public Religion and Secularization Debate", dalam Gabriele Marranci, Muslim Societies and the Challege of Secularization, (New York: Springer, 2010), 21.

Wulansari, Sintha Dwi dan Setiawan, Achma Hendra, Analisis Peranan Dana Zakat Produktif Terhadap Perkembangan Usaha Mikro Mustahik (Penerima Zakat), Diponegoro Journal Of Economics, Volume 3, Nomor 1, (2014), 1-15.

\section{Daftar Wawancara}

Aziz Muslim, selaku amil pada LAZ UIN Sunan Kalijaga.

Khuriati, selaku Kepala Sekolah TK Harapan Aisyah sebagai salah satu Muzakki zakat profesi.

Sakinah, selaku guru matematika SMPN 2 Kuok sebagai salah satu Muzakki zakat profesi.

Satrio, admin akun instagram Halalexpo-id.

\section{Website}

Halalexpo-id, Instagram, Postingan 27 Maret 2019

VOA-Islam.com, Patut Ditiru, Karyawan BRI Rela Dipotong Gajinya 2,5\% untuk Berinfak",http://www.voaislam.com/read/indonesiana/2013/04/30/24282/patut-ditirukaryawan-bri-rela-dipotong-gajinya-25-untuk berinfak/\#sthash.DvflG2dl.dpbs, akses pada Selasa, 30 April 2013. 